\title{
Settlements and dwellings of Adyghe people
}

\author{
Zalina Unezheva* and Aminat Sultanova \\ Kabardino-Balkarian State University named after Kh.M. Berbekov, 360004, Nalchik, Russia
}

\begin{abstract}
The article discusses the differences and monotony of the traditional types'settlements of the Circassians, the forms of estates and courtyards.All the main elements of the dwelling are considered in detail: its layout, building material and construction technique, the shape of roofs, the structure and types of hearths and their location, interior, home furnishings and utensils etc. The article covers the period IV - XIX centuries.
\end{abstract}

\section{Introduction}

Studying the settlements and dwellings of the Circassians, we directly consider the location, natural and climatic conditions of the North Caucasus. The North Caucasus is one of such regions of our planet, where people have lived since ancient times, or rather from the Paleolithic period (ancient non-stone age). Its rich flora and fauna have always attracted people. The features of the relief, natural and climatic conditions and the region location at the crossroads between Europe and Asia, on the border of the steppes, which for thousands of years served as a road for nomads moving from east to west and from north to south, had a decisive impact on the ethnic composition formation of the region [1].

During the Paleolithic era, mainly natural caves and rock sheds served as dwelling places. In addition, there were still primitive human shelters, such as a hut and a shed, of which there were many in the mountains. Starting from the IV century, settlements of the Circassians appeared, whose dwellings were rectangular, covered with reeds. If we are talking about statehood, then 3 thousand years ago it also existed among the Circassians. It was borrowed from the Greeks or built by Adyghe people, to be more precise. And there was urban culture, says Mira Unarokova, ethnographer, candidate of historical sciences. Today there is not a single stone structure left, all of this is underground, at a depth of 3 meters. On modern Anapa there was a rural harbor, excavations showed that about 150 such towns were recorded.

\section{Settlement of the Circassians}

\subsection{Settlement of the Circassians in the $5^{\text {th }}-12^{\text {th }}$ centuries}

Most of the Circassian settlements appeared in the 5th-6th centuries. But, also, some of the Circassians stayed in rather large settlements, such as Koshehablskoe, Tamanskoe,

\footnotetext{
${ }^{*}$ Corresponding author: z.unezheva@mail.ru
} 
Takhtamukayskoe, Pshikuykhablskoe and others. The baron's book "The Fifth Journey to Turkey, Persia and India" where he happened to meet the locals: "the Circassians arranged their settlements in a treeless area in the form of a camp, or a circle, constructing a dwelling from the branches of reeds, hazel trees and other lightweight materials" [2]. During the Middle Ages, the most common among the Circassians were rectangular turluch and adobe houses, erected both on the foundation and without it [3]. Such houses were ideal for moving, caused by the military life of the Circassians. In case of danger, they took refuge in the forest. The Adyghe clan and tribal nobility, under the influence of the Greeks, built castles and courtyards. They were built of hewn and chipped stone, the floors were paved with stone slabs, and there were courtyards with wells. Even during the Middle Ages, the Adyghe tribes still had stone fortifications and castles, with the help of which Adyghe people defended their independence.

\subsection{Settlement of the Circassians in the $12^{\text {th }}-19^{\text {th }}$ centuries.}

Settlements of Kabardians in the 15th-18th centuries often had the shape of a circle or a square, along the perimeter of which dwellings were located, and in the middle, there was a vast courtyard [3]. Such a settlement had one or two exits. One exit served as the main one. Circassian auls were defended by stone walls, towers, feudal castles. Every night there was a guard at the tower. Settlements of Kabardians in Russian and Ottoman sources of the 16th-17th centuries. were called - taverns (tavern - Arabic pumpkin). Probably this name got from the round shape of the layout of most taverns. Most of the taverns were located in open areas. The French traveler Jean de Luc, noting the nature of the settlement of the Kabardians in the forests, writes that "the countries of the Circassians, stretching for 25 days of travel, were generally extremely poorly populated, since the places where the forest was rare were not inhabited. Only the most eastern of the Adyghe tribes, the Kabardians dared to settle in an open area, building their settlements in the form of a circle or quadrangle - traditional settlements of the Kabardians living in a relatively deforested area had a denser building and orderly layout. External danger forced the residents here to hide their settlements behind a solid fence or to build dwellings in a circle or a square. "Settlements of such a plan had a relatively clear layout, in which residential and utility rooms of the structure were erected in a circle or along the perimeter of the square, and the entrance was turned inward. The middle of such a settlement apparently served for keeping domestic animals - horses, cattle, dogs, etc. there was a water storage at the main entrance. The houses of the Circassians were simple: they were made of fence and covered with clay inside and out. In Kabardian villages, each house had, and some still have, a stove to meet the needs of the owner and heat the dwelling" [4]. Such settlements consisted of 40 or 50 similar houses covered with reeds or straw and located in a circular pattern.

However, now it is known that such a capacity for organizing people during the construction of settlements existed long before the times described by travelers. Only in the first half of the 19th century, the planning of settlements became free, when the struggle between the feudal lords and the raids of enemies had already ended. And in the 60s of the XX centuries. there was an enlargement of the Kabardian settlements. At the beginning of the XIX century. Klaptor visited Kabarda and he noted: "The same piece of land has been used for two or three years, and when it becomes unusable, the Circassians move to another place". The author even drew attention to the fact that the Circassian auls had no names [5]. 


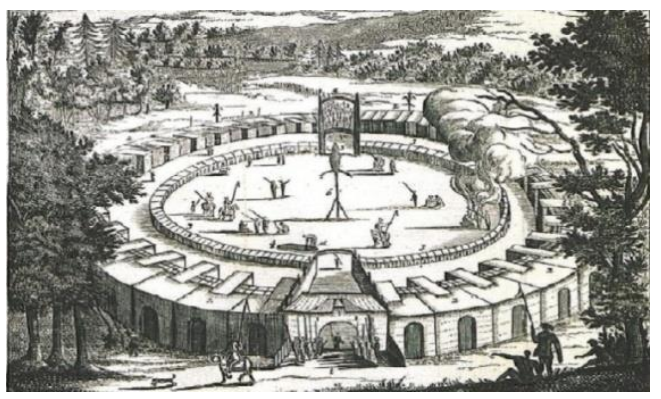

Fig. 1. Scheme settlements of the Circassians. German draftsman, copper engraver, illustrator Christian Gottfried Heinrich Geisler, who in 1793-1794 participated in the expedition of P. S. Pallas to the Caucasus as an artist and engraver, captured in his writings a traditional Circassian settlement in the form of a circle.

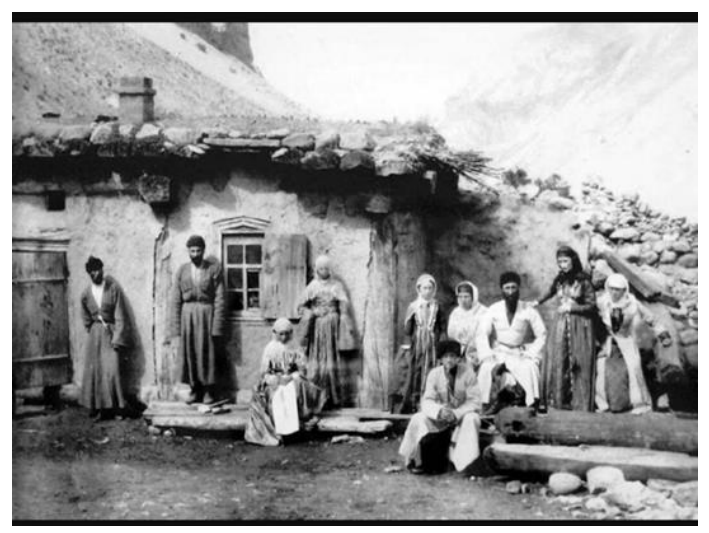

Fig. 2. Dwellings of the Circassians in the $19^{\text {th }}$ century

\section{Building materials and rules for building a Circassian dwelling}

The houses were built according to special rules. The first barrel had to be hammered by a decent person. Wooden nails were used instead of iron ones. Further weaving was done with fresh twigs. The entrance passage doors were left. The rods in the window openings twisted and intertwined in the opposite direction. The roof was covered with thatch, reed or sedge. "In order to prevent burning out, the wall at which the fireplace was arranged had to be covered with stone tiles or coated with a thick layer of clay in order to prevent it from burning out. Sometimes, instead of this, for example, in Adygea, Circassia and Kabarda, even a small gap was arranged in the wall, in which the chimney came out, while he himself was essentially outside the volume of the dwelling"[6].

The houses could differ in architecture, but not the hearth, which was the sacred place of the Circassians at all times. It was erected simultaneously with the construction of the dwelling. Among the Kuban Circassians, the hearth was located most of all near the longitudinal or lateral outer wall of the house, in the Black Sea Circassians the hearths had to adjoin the inner partition, among the Kabardians and Besleneevites it was located in a special poverty, more often the removal of the hearth chimney border beyond the house perimeter is visible. 


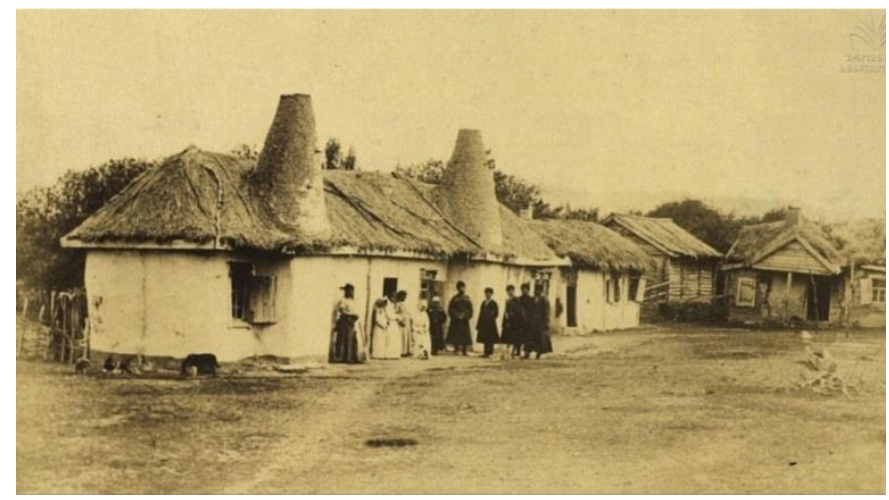

Fig. 3. Tourluch houses of Abazins. XIX century.

\section{Dwelling houses}

\subsection{Alezhevs'House}

We are interested in the same questions as for all Circassian peoples, what was the ancient Nart house like? What was it like and what did it look like? In our article we will try to find the answers.

Along with estates and fences, the settlement complex also included public places. So, since ancient times, the places where the khase (council) was held, the guest house (khyakIesh) of the aul owner or another powerful person, as well as the smithy, which was a kind of men's club [7], have been a kind of centers of attraction in villages since ancient times.

On the current border of the Krasnodar Territory and the Republic of Adygea, not far from the village of Kabukai, he of the Alezhevs' house was built. It was here that the Hasas, the council of the Narts, gathered. People's meetings were held, the decisions that could fully become the basis of the Circassian etiquette of Adyghe Khabze were made.

The Nart epic gives an exact description of this place. The house stood in a ravine to the south, where the whole area was clearly visible from this place. The house was 33 meters long, consisted of several rooms, massive entrance doors. The pillar of the house, as it is sung in the song about the sledges, can be compared to the pillar of the national building in Maykop. There is a lot in common between the Greek architecture of the archaic period and the Alezhevs' house, according to the statements of the artist and architect Abdulakh Bersirov. The same terraces, the same columns, the builders of Athens, even after switching to stone architecture, carried this style practically unchanged to create their acropolis and cities.

\subsection{Dwellings in the $15^{\text {th }}$ century}

During this period, the Circassian tourluch houses were familiar for unexpected resettlement. The houses of stone seemed to them like cowardice. Tourluch houses, in addition, were more consistent with the climatic areas. The dwelling consisted of one or two rooms, the hearth was most of all at the longitudinal or lateral outer wall of the house. 


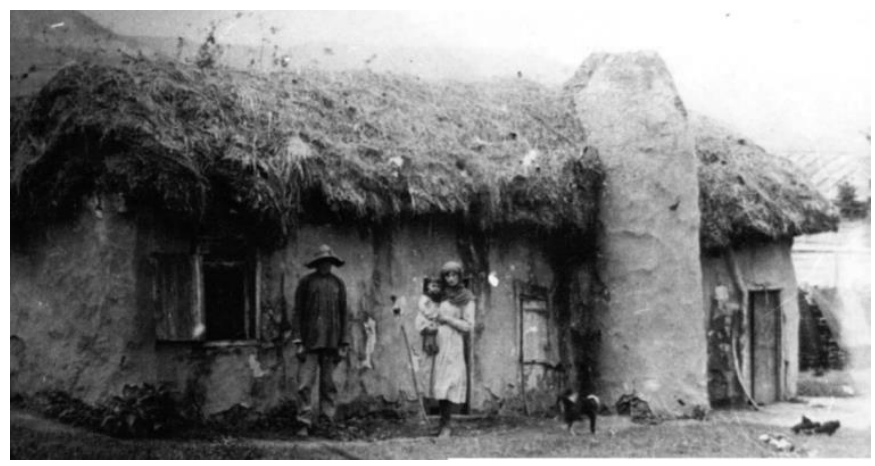

Fig. 4. Dwellings of Kabardians in the $17^{\text {th }}-19^{\text {th }}$ centuries

\subsection{Dwellings of the Circassians in the $6^{\text {th }}-{ }^{17 \text { th }}$ centuries}

A dwelling made of stone in the early Middle Ages existed in many regions of the Circassians residence. One house of this type was excavated by B. Ye. Degen-Kovalevsky at a settlement (kalezh. - K. U.) of the 6th-8th centuries near the modern village of KBR, Zayukovo, Baksan district. The building had an area of about 60 sq. m, its walls, piled dry from cobblestones, were plastered outside with lime mixed with clay, the floor was paved with pebbles and rubble. The dwelling consisted of two or three living quarters, in the larger of which, against the back wall, there was a deep hearth lined with ceramic tiles. Another hearth was in a smaller room. In addition, in the courtyard not far from the dwelling, a pit-furnace was found in the form of a truncated cone, with its wide base facing downward. The depth of the pit is 1.5 m.B.Ye. Degen-Kovalevsky compares it with the Transcaucasian tandoor.

\subsection{Dwellings of the 17th century}

The Cherkeskoe structure was very simple and easy to work with. The houses are built in an oblong quadrangle, at the corners of the pillars connected by crossbeams, in the middle of the fence coated with clay outside and inside, the roof is thatched from reed. The floor was earthen. The roof was covered with thatch, reed or sedge.

J. Polotsky wrote in 1798: "The dwellings of the Circassians are not the houses in the full sense of the word; rather, they are large baskets made of carefully woven rods, plastered with clay on top and covered with reeds. Such a village remained in one place for no more than 4-5 years" [8]. The traditional dwelling of the poor Circassians is a house made of twigs coated with clay [9]. It refers to the end of the XX century.

\subsection{Interior decoration of the 15th-18th centuries}

Inside, the walls are clean whitewashed; a fireplace against one wall, opposite a low bed (sofa), covered with a carpet or felt; above it hangs a military harness, a saber, a gun, a pistol, and other household belongings, mattresses, and pillows are tidied up to one corner. The stove was small, adobe, sometimes on a frame made of twigs, although an open hearth was also characteristic. This was the home of the first Prince and the poorest servant [10]. 


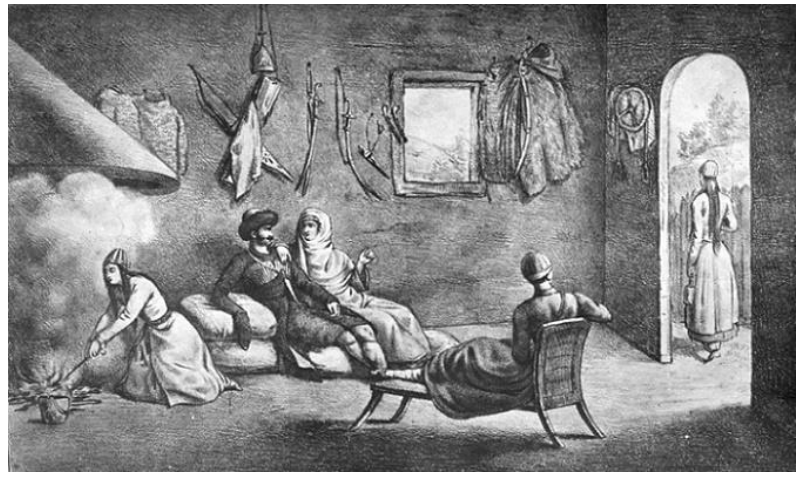

Fig. 4. Interior decoration of the $15^{\text {th }}-16^{\text {th }}$ centuries Circassians

\section{Conclusion}

Considering the dwellings and settlements of the Circassians of the 18th - 19th centuries, it seems logical to note that the Circassian people in rural settlements had poor houses both in construction and in the interior. All the building material used was from a natural resource. One fact of this article is very striking: in the modern world of the Adyghe people, like the other, it is not possible to notice two identical houses among all the many. So how could it be that 40-50 families could negotiate and build the houses according to the same scheme and at the same time? The answer to this question can only be how highly developed the educational culture, mutual respect and reverence for the elders, as well as the decision of the elders was the law for everyone. This is, obviously, the beginning of the Circassians'traditions to visit, or, more precisely, to go on a visit without letting know beforehand, as to meet a guest at home and as a family member, caring for him as a father, brother, etc.

By the $18^{\text {th }}$ century, the buildings were still quite simple. In some cases, class needs were the reason and basis for striving for the best. It was from the end of the $19^{\text {th }}$ century that building materials started being improved.

\section{References}

1. K.Kh. Unezhev, The culture of Adyghe people (Circassians) and Balkars (Publishing house - "Elfa", 2003)

2. J.B. Tavernier, Les six Voyages en Turque, en Perse et aux Inde (Paris, 1681).

3. T.Kh. Kumykov, I.M. Mizieva, Kabardino-BalkarianHistory (Publishing house Nalchik "Elbrus", 1995).

4. M.M. Orkvasov, Materials on the architecture of Circassian dwellings (Nalchik, 2011).

5. Z.B. Kipkeeva, NorthCaucasus in Russian Empire: peoples, migrations, territories (Stavropol State University, 2008).

6. V.P. Kobychev, Settlements and dwellings of the NorthCaucasuspeoples in the 19th20th centuries, (1982)

7. M.N. Gubzhokov, Section on the culture of the Circassians for the "History of Adygea from ancient times to 1920, (2009).

8. G.Kh. Mambetov, From the culture and life of the Kabardians and Balkars (early 17th 70th 20th century), "Elbrus", (2006). 
9. A.L. Narochnitsky, History of the North Caucasus peoples (late 18th century - 1917) (Moscow "Nauka", 1988).

10. S. Bronevsky, Caucasians 1750-1820 (Publishing house - "In the Selivanov sky printing house", 1923). 